\title{
Microfluidic-Based Approaches for Foodborne Pathogen Detection
}

\author{
Xihong Zhao ${ }^{1, *} \mathbb{0}$, Mei $\mathrm{Li}^{1}$ and Yao Liu ${ }^{2, *}$ \\ 1 Research Center for Environmental Ecology and Engineering, Key Laboratory for Green Chemical Process of \\ Ministry of Education, Key Laboratory for Hubei Novel Reactor \& Green Chemical Technology, School of \\ Environmental Ecology and Biological Engineering, Wuhan Institute of Technology, Wuhan 430205, China \\ 2 School of Pharmacy and Food Science, Zhuhai College of Jilin University, Zhuhai 519041, China \\ * Corresponding author: xhzhao2006@gmail.com (X.Z.); yauldliu@163.com (Y.L.)
}

Received: 20 August 2019; Accepted: 16 September 2019; Published: 23 September 2019

\begin{abstract}
Food safety is of obvious importance, but there are frequent problems caused by foodborne pathogens that threaten the safety and health of human beings worldwide. Although the most classic method for detecting bacteria is the plate counting method, it takes almost three to seven days to get the bacterial results for the detection. Additionally, there are many existing technologies for accurate determination of pathogens, such as polymerase chain reaction (PCR), enzyme linked immunosorbent assay (ELISA), or loop-mediated isothermal amplification (LAMP), but they are not suitable for timely and rapid on-site detection due to time-consuming pretreatment, complex operations and false positive results. Therefore, an urgent goal remains to determine how to quickly and effectively prevent and control the occurrence of foodborne diseases that are harmful to humans. As an alternative, microfluidic devices with miniaturization, portability and low cost have been introduced for pathogen detection. In particular, the use of microfluidic technologies is a promising direction of research for this purpose. Herein, this article systematically reviews the use of microfluidic technology for the rapid and sensitive detection of foodborne pathogens. First, microfluidic technology is introduced, including the basic concepts, background, and the pros and cons of different starting materials for specific applications. Next, the applications and problems of microfluidics for the detection of pathogens are discussed. The current status and different applications of microfluidic-based technologies to distinguish and identify foodborne pathogens are described in detail. Finally, future trends of microfluidics in food safety are discussed to provide the necessary foundation for future research efforts.
\end{abstract}

Keywords: foodborne pathogens; microfluidic chip; rapid detection; food safety; biosensors

\section{Introduction}

With the rapid development of the economy and the continuous improvement of living conditions, people today are paying more and more attention to health issues. At the same time, whether food is safe or not is also closely related to people's health, therefore, it is also very important to ensure the safety of food. Unfortunately, people sometimes unconsciously eat some foods that are harmful to the body in their daily lives, for example, food contaminated by pathogens [1,2]. If people eat food containing foodborne pathogens such as Staphylococcus aureus, Salmonella, and Escherichia coli O157:H7, they may suffer vomiting or even death, triggering consumer panic [3]. According to the statistics of Parisi et al. a quarter of the world's people are at higher risk of foodborne illnesses due to the current inefficient detection technology of bacteria, the imperfect food supervision system and high-speed economic development [4]. Overall, new strategies should be applied to improve food safety. 
Foodborne illnesses are caused by pathogens or their toxins when they are contained in food or water. Pathogens causing foodborne illnesses include bacteria, viruses, fungi, and parasites [5]. For example, people infected by pathogenic Escherichia coli (E. coli) often experience severe diarrhea, and there are nearly 1.7 billion cases of diarrhoea every year in the world. More seriously, approximately 760,000 children under the age of five die each year from diarrhoeal diseases [6-8]. Most diseases are attributed to the common foodborne pathogens that include Listeria monocytogenes, E. coli O157:H7, Staphylococcus aureus, Salmonella enterica, Bacillus cereus, Campylobacter jejunum, and Clostridium perfringens [9]. Therefore, the effective detection of these pathogens is important.

At present, there are many methods to identify and detect pathogens, such as direct smear microscopy, nucleic acid hybridization, gene chip, polymerase chain reaction (PCR), gas chromatography and high performance liquid chromatography [10]. However, the most classic method is the plate cultivation method. However, this method requires three to seven days for bacterial culture, making it inappropriate for the rapid on-site detection of pathogens [11]. Additionally, PCR is also sometimes prone to false positive results due to DNA contamination $[12,13]$. Thus, to assess food safety, it is necessary to develop a rapid and simple method with high sensitivity, good reproducibility, and good on-site interpretation ability [14].

For this reason, microfluidics with the advantages of portability, miniaturization and automation have been widely introduced to detect different substances in the fields of chemistry, biomedicine, optics and information science, such as dyes, bacteria or heavy metals $[15,16]$. Microfluidics are typically made of silicon, glass, quartz or thermoplastic materials. Then, micro-processing techniques are used to integrate micro-valves, micro-pumps, micro-mixers, micro-electrodes onto a micro/nanoscale chip to form a network-like system that can achieve pretreatment, mixing, reaction, separation or detection of the sample, which is not possible in traditional laboratories [17]. Microfluidics have several different types of basic mixer structures, as shown in Figure 1. For example, a microfluidic fluorescence quantitative PCR system with pneumatic valve and a tree structure was developed by using 3D printing technology. Due to its good temperature uniformity and thermal conductivity of PCR-based microfluidics, the rapid detection of hepatitis B virus nucleic acid in blood samples was realized in $50 \mathrm{~min}$ [18]. At present, the miniaturization, integration and automation of these devices combined with multiple processes have made microfluidic chips popular options for use in a wide range of fields, and the following are the applications and research status of microfluidics for bacterial detection.
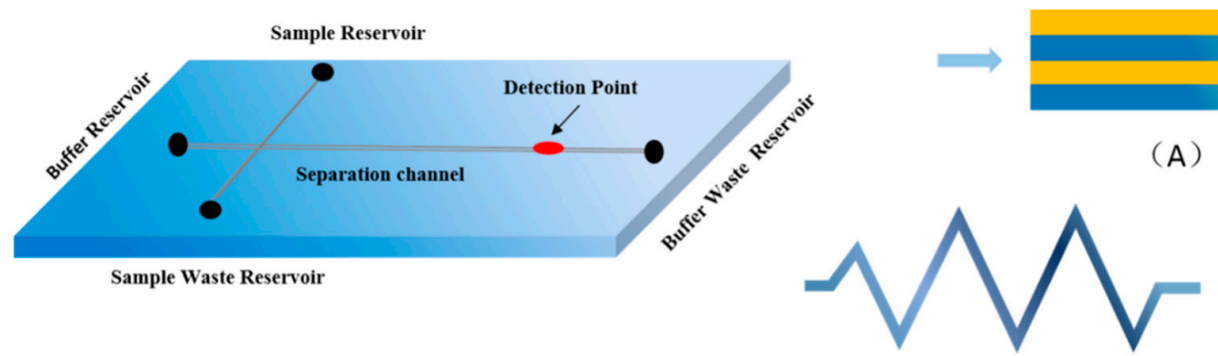

(B)

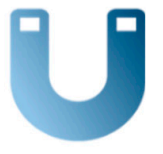

(C)

Figure 1. The structure of common microfluidic chip channel and variable styles of passive mixers. (A) Lamination; (B) Zigzag channels; (C) Serpentine.

In general, traditional microbial culture techniques require the use of tubes, culture dishes, multiwall plates and flasks, which makes the detection of bacteria more complicated. However, Wang et al. only combined a nano-dielectrophoretic enrichment-based microfluidic platform with surfaced-enhanced Raman scattering (SERS) to successfully and automatically monitor Escherichia coli O157:H7 in drinking water (the detection limited to single cell level) [19]. Wan et al. also developed a digital microfluidic system based on loop-mediated isothermal amplification (LAMP) for the detection of pathogen nucleic acids. In this experiment, only $1 \mu \mathrm{L}$ of LAMP reaction sample that belong to 
purified Trypanosoma cruzi DNA was required, which reduced a 10-fold of reagent consumption compared to conventional LAMP. If the sample of LAMP is unknown, it also can be finished in 40 min with a detection limit of 10 copies/reverse. Moreover, the system can be thermally adjusted in real time, which is possible for the miniaturized, portable and on-site application in detecting bacteria in the future [20]. However, in order to reduce the costs and improve the portability of detection, high-performance materials such as paper-based microfluidic chips have been applied. Jokerst et al. designed a paper-based assay device for detecting E. coli O157:H7, Salmonella typhimurium and Listeria monocytogenes. The paper that was used for the preparation of the microfluidic system was wax printing on filter paper, which was achieved by measuring the color change of the response of the enzyme associated with the pathogen of interest to the chromogenic substrate. When combined with an enrichment procedure, the method allowed for an enrichment time of $12 \mathrm{~h}$ or less and was able to detect the bacteria in meat at a detection limit of 10 colony-forming units $/ \mathrm{cm}^{2}$ [21].

As described above, microfluidic devices are simple, automated, and portable miniaturized systems that can perform functions more efficiently and conveniently than the common techniques such as PCR and LAMP [22,23]. Although there are some reviews on the application of microfluidic chip technology in food safety, their overall systematisms and integrity are not enough. This review not only describes the latest developments in integrated-microfluidic systems for detecting foodborne pathogens, but also discusses the most promising strategies to address current challenges for the faster and more accurate detection of foodborne pathogens by microfluidic chips.

\section{Microfluidic Chips}

Microfluidic chips refer to the science and technology of systems that process or use very small volumes of liquids in channels with the dimensions of tens to hundreds of micrometres [24,25]. Microfluidics also are described as lab-on-a-chip (LOC) or miniaturized total analysis systems ( $\mu$-TAS), which integrate the sample preparation, reaction, separation, detection, and other basic operating units onto a centimeter-scale chip with a network of microchannels [26]. Microfluidics is an interdisciplinary field, including aspects of physics, chemistry, engineering, and biotechnology [24,27]. Due to the characteristics of electro-hydrodynamics with small size parameters and short detection times, electrodynamics, and thermal capillary phenomena, microfluidic devices have been developed to address specific scientific problems that are not able to be easily solved by traditional techniques [28,29].

Manz et al. first proposed the concept of a micro total analysis system ( $\mu$-TAS) [30]. In 1992, micro-electro-mechanical machining technology was used to etch micro-pipes on flat glass to prepare a chip capillary electrophoresis device, and the device realized the separation of fluorescently labeled amino acids and pioneered microfluidic chip technology [31]. In 1995, Woolley and Mathies successfully performed DNA sequencing using their own electrophoresis chip system, reading 150 bases in 540 s with an accuracy rate of $97 \%$ [32]. Subsequently, Woolley et al. integrated PCR and capillary electrophoresis on a microfluidic chip, facilitating genetic analysis [33]. In 1998, Brahmasandra et al. (1998) used photolithography technology to fabricate a microfluidic chip that included a liquid sampler, a mixer, a positioning system, a temperature-controlled reaction chamber, an electrophoresis separation system, and a fluorescence detector system for DNA analysis [34]. In 2000, Anderson et al. developed a highly integrated chip that can be used to process a series of complex processes for multiple samples, and this device was applied for extracting concentrated nucleic acids from a liquid sample for microcrystalline chemical amplification, enzymatic reaction, hybridization, mixing, and measurement, allowing more than 60 consecutive operations of a dozen reactants [35].

Microfluidic devices are mainly operated by manipulating fluids in microfabricated channel and chamber structures. Additionally, microfluidics can be combined with diverse detection techniques including PCR, LAMP, mass spectroscopy, or fluorescence spectroscopy, for on-chip or after-chip detection of analytes [36-39]. Microfluidic chips are made of silicon, glass, quartz, organic polymer, and composite materials by micromachining technology. Figure 2 shows the preparation process of polydimethylsiloxane (PDMS) microfluidics. Recently, paper-based microfluidic chips with low cost, 
portability and easy operation have been developed in the food industry [40]. The selection of a certain material for a device is important for its functions. The different materials exploited for the fabrication of microfluidic chips and the advantages and disadvantages of these materials are listed in Table 1.

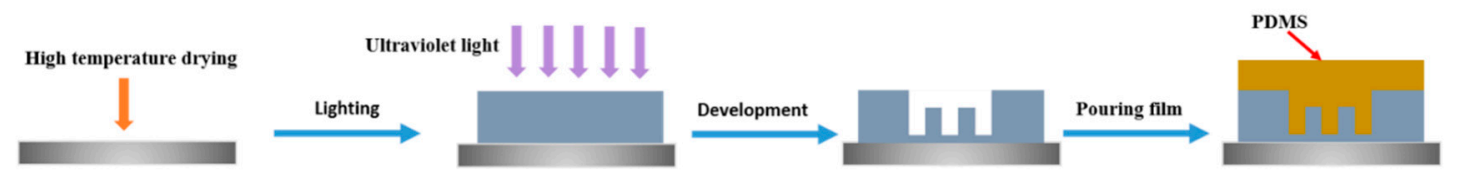

(1) Cleaning of silicon wafer

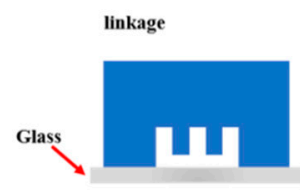

(8) PDMS microfluidic chip
(2) Addition of SU-8 photoresist

(3) Preparation of photoresist master

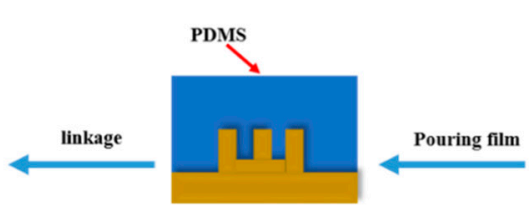

(7) Preparation of PDMS chip

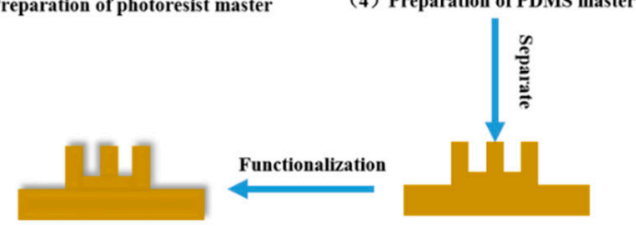

(6) Functionalization of PDMS mold (5) Reverse master of PDMS

Figure 2. The preparation process of a polydimethylsiloxane (PDMS) microfluidic chip by the molding method.

Table 1. The application of a microfluidic system made of different materials.

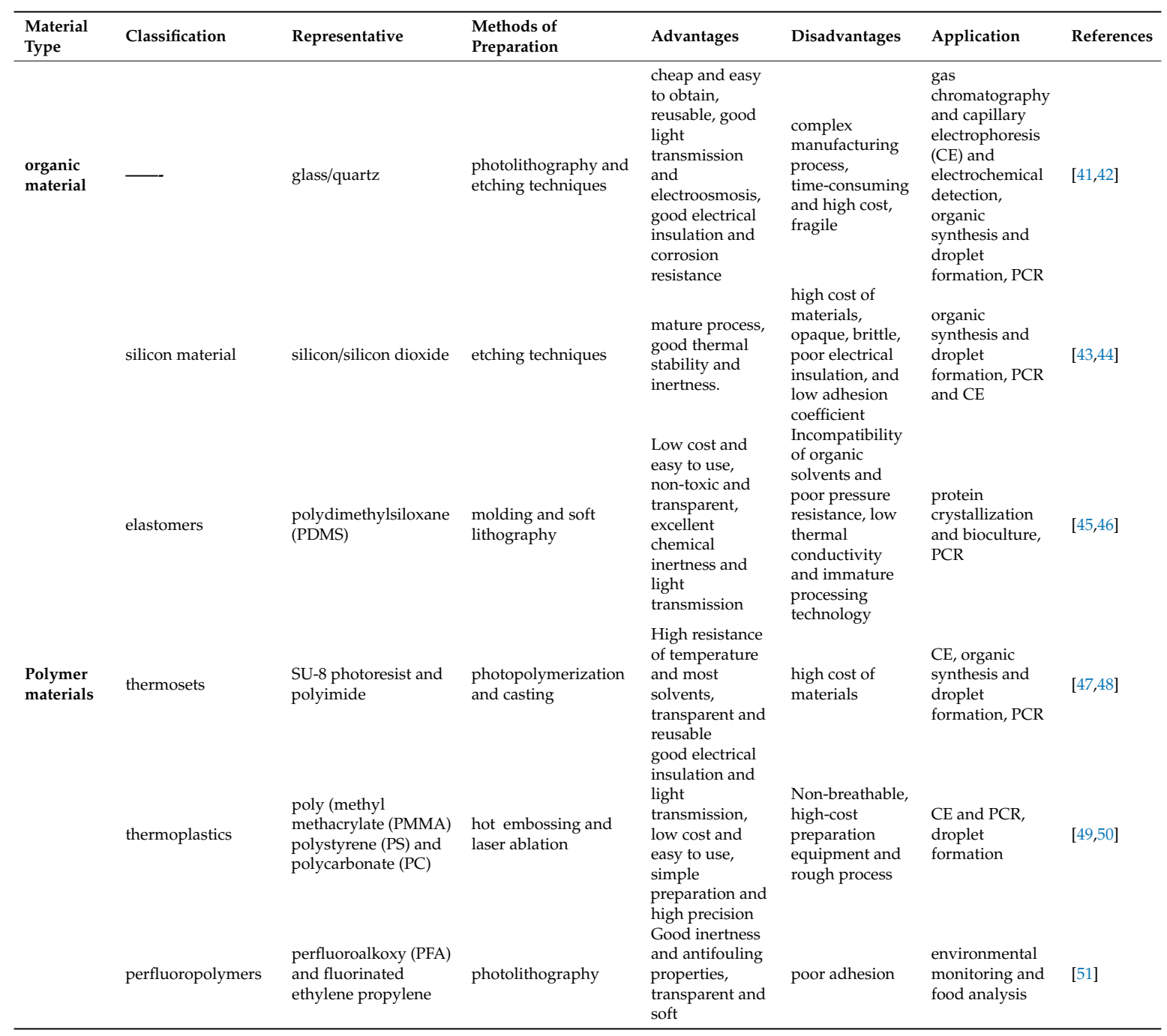


Table 1. Cont.

\begin{tabular}{|c|c|c|c|c|c|c|c|}
\hline $\begin{array}{l}\text { Material } \\
\text { Type }\end{array}$ & Classification & Representative & $\begin{array}{l}\text { Methods of } \\
\text { Preparation }\end{array}$ & Advantages & Disadvantages & Application & References \\
\hline \multirow[t]{3}{*}{$\begin{array}{l}\text { Special } \\
\text { materials }\end{array}$} & hydrogels & $\begin{array}{l}\text { polyvinyl alcohol } \\
\text { (PVA) }\end{array}$ & $\begin{array}{l}\text { photopolymerization, } \\
\text { casting }\end{array}$ & $\begin{array}{l}\text { high } \\
\text { permeability } \\
\text { and controllable } \\
\text { aperture, } \\
\text { allowing small } \\
\text { molecules or } \\
\text { even biological } \\
\text { particles to } \\
\text { diffuse, and } \\
\text { biocompatible }\end{array}$ & difficult to store & 3D bioculture & [52] \\
\hline & ceramics & polysiloxane & $\begin{array}{l}\text { soft lithography and } \\
\text { laser ablation }\end{array}$ & $\begin{array}{l}\text { high resistance } \\
\text { of temperature } \\
\text { and pressure }\end{array}$ & $\begin{array}{l}\text { poor light } \\
\text { transmission, } \\
\text { fragile }\end{array}$ & $\begin{array}{l}\text { suitable for } \\
\text { applications } \\
\text { under harsh } \\
\text { conditions }\end{array}$ & [53] \\
\hline & paper & analysis filter paper & $\begin{array}{l}\text { photolithography and } \\
\text { printing }\end{array}$ & $\begin{array}{l}\text { high } \\
\text { permeability } \\
\text { and low cost, } \\
\text { portable and } \\
\text { easy to use }\end{array}$ & $\begin{array}{l}\text { easy to damage } \\
\text { and disposable }\end{array}$ & bioculture & [54] \\
\hline
\end{tabular}

Compared to traditional methods such as PCR, enzyme-linked immunosorbent or DNA probes, microfluidic devices allow for a flexible combination of multiple operating units and overall controllability, so some steps such as sample pretreatment, mixing or reaction can be integrated into a single chip. Additionally, because the channel structure in the chip is micron-scale or even nanoscale, it has a high specific surface area, a high diffusion coefficient, and fast heat transfer, effectively accelerating the reaction in the channels and greatly shortening the overall analysis time $[55,56]$. For example, Zhang et al. developed a novel microfluidic liquid phase nucleic acid purification chip that can selectively separate DNA or RNA from $5000 \mu \mathrm{L}$ to single cell bacterial cells. The sample volume is only $1 \mu \mathrm{L}$ or $125 \mathrm{~nL}$, which can be directly quantified by a chip in approximately $30 \mathrm{~min}$. Thus, these small devices also require much lower amounts of reagents and samples, which greatly reduces the cost of detection and enables fast and low-cost detection [57]. Nevertheless, everything in the world has two sides. Without exception, microfluidic technology has its own disadvantages. For example, there is no skillful and mature technique for preparing a good microfluidic system and there is a lack of good and perfect preparation materials. Overall, the advantages of microfluidic technology confer promising potential for high-efficiency screening, environmental monitoring, clinical monitoring, on-site analysis, and DNA sequencing applications.

\section{Sample Preparation in Microfluidics}

\subsection{For Single Component}

For a single component, there is no special and complicated separation and purification treatment of the sample needed. However, how to improve the sensitivity, speed and accuracy of the detection component is particularly important. At present, the molecular technologies, such as PCR, first need to extract the DNA of the bacteria, and also add the required reagents by labour, which is extremely time-consuming and troublesome. In addition, if the concentration of the analyte does not reach a measurable level, it is also necessary to concentrate the bacterial DNA concentration multiple times [58]. Therefore, other methods, such as optical analysis, fluorescence detection or electrochemical analysis, can avoid the pretreatment of samples and achieve automated, simple and rapid bacterial detection.

PCR is routinely applied to detect some components in food. Therefore, Tachibana et al. developed a new PCR-based microfluidic technique for the successful detection of $0.031 \mu \mathrm{g} / \mu \mathrm{L}$ of E. coli O157:H7 genomic DNA, which was completed in $18 \mathrm{~min}$ and provided a new platform for a rapid, simple and low-cost detection assay for this pathogen. However, there is still a need to further improve the bacterial pre-enrichment and DNA purification steps to lower the detection limit of E. coli O157:H7 in the integrated PCR system $\left(10^{3} \mathrm{CFU} / \mathrm{mL}\right)$ [59]. Zhang et al. used magnetic silica beads and a special coaxial channel to optimize the detection of E. coli O157:H7. This special channel allows the improved 
separation and capture of the lysed DNA of E. coli O157:H7 using magnetic materials. With this modified system, E. coli was successfully detected by microfluidic PCR with a detection limit of only $12 \mathrm{CFU} / \mathrm{mL}$ [57].

To lower the cost and the difficulty of sample preparation, and increase the portability of testing, high-performance materials, such as paper-based microfluidic chips, are being developed to detect such pathogenic bacteria. Wang et al. proposed a paper-based impedance immunosensor for detecting E. coli O157:H7. Gold nanoparticles grew on the working electrode and anti-E. coli O157:H7 antibody immobilized on the paper electrode was used to capture the target bacteria, which changed the resistance of the reaction in different environments and successfully detected E. coli O157:H7 from ground beef (LOD of $1.5 \times 10^{4} \mathrm{CFU} / \mathrm{mL}$ ) and cucumber (LOD of $1.5 \times 10^{3} \mathrm{CFU} / \mathrm{mL}$ ) [60]. Moreover, there are also numerous introductions and research on paper-based microfluidics. Cate et al. reviewed the preparation, principles, and application of paper-based microfluidic chips [61]. Liu et al. also described recent developments, trends, and challenges of paper-based microfluidic chips for food safety applications [62]. Therefore, the detection process for pathogens is mainly to optimize the detection technology.

\subsection{Complex Components in Food Matrix}

To date, most techniques that are used to determine some experimental samples are relatively simple just for a single component. However, for practical use, complex samples and variability in environmental conditions may result in reduced sensitivity and specificity of microfluidic technology, so a device should be designed to analyze more complex samples, such as soil, sewage, or food samples [63]. Due to the physical and chemical properties of each component to be tested in the sample may not be much different than those of single components (such as the detection of different bacteria), it may be difficult to achieve simultaneous detection of multiple components. Additionally, the variety and content of other substances in complex food matrices may interfere with the detection and reduce the accuracy of the assay. For example, if the aim is to detect E. coli in food samples, there is definitely more than one kind of bacteria in this concentrated sample. Thus, in order to eliminate these interferences, some specific bio-recognition molecules can be integrated into the detection system. It is by increasing the concentration and specificity of the sample that makes it easier to detect the components from complex mixtures.

\subsubsection{Special Materials and Sampling Methods}

The main cause of low reproducibility or the inability of microfluidic devices to detect analytes in complex food substrates is due to the concentration of analytes below the detection limit. Thus, the separation and enrichment of targets from a food matrix are needed to increase the efficiency for detecting analytes. The sample concentration can be improved using a variety of techniques such, as magnetic beads or filter membranes. Among them, the magnetic beads generally have superior paramagnetism, such as $\mathrm{Fe}_{3} \mathrm{O}_{4}$, which is able to separate from the sample to be tested with the help of a magnetic field and a rich surface-active group. The filtration membranes are usually made of a variety of ultra-high-performance polymers, which have acid and alkali resistance or oxidation resistance to achieve the separation and purification of the samples. Furthermore, since the reaction is performed in a microfluidic system, different injection methods may improve the concentration of the target $[18,64]$.

Immunomagnetic separation (IMS) can be used to concentrate bacterial cells present at lower concentrations, but it is just suited to a small volume sample (e.g., $1 \mathrm{~mL}$ ), which is far smaller than the large volume of enrichment culture (e.g., $250 \mathrm{~mL}$ ). To address this issue, Ganesh et al. integrated IMS of bacterial cells into microfluidic devices for the preconcentration of $50 \mathrm{~mL}$ volume samples. PCR was then applied for the qualitative and quantitative detection of the E. coli O157:H7 in less than two hours. This platform decreased both the required sample volume and the overall time of the reaction [65]. Oh et al. combined loop-mediated isothermal amplification (LAMP) with a disk-shaped centrifugal microfluidic device to successfully detect four foodborne pathogens (Escherichia coli O157:H7, Salmonella 
typhimurium, Vibrio parahaemolyticus and Listeria monocytogenes) in contaminated milk samples with bacteria. The use of Eriochrome Black T (EBT) in the system allowed the colorimetric detection of the LAMP reaction, and this process enabled a fully automated detection of bacteria with a detection limit of 10 bacterial cell level in $65 \mathrm{~min}$ [66]. However, the colorimetric measurement of this platform is identified by the naked eye, which may cause some errors in the interpretation of the experimental results. For this reason, Sayad et al. utilized calcein as an indicator and combined it with LAMP for a genotypic analysis of eight strains of the foodborne pathogens E. coli O157:H7, Salmonella and Vibrio cholerae, for a total of 24 pathogenic bacteria being detected. The result of the colorimetric method was analyzed and transmitted to a smartphone using a developed electronic system that interfaced with bluetooth wireless technology in $60 \mathrm{~min}$. This system avoids artificial subjective errors and achieves a fully automated, quick and on-site test [67].

The above experiments use special materials to detect bacteria, but filter membranes can also be used to increase the concentration of the target. Li et al. used a poly sulfone hollow-fiber membrane module to separate and concentrate bacterial cells from chicken homogenates in cross-flow microfiltration. This special microfluidic system can effectively recover $70 \%$ of the analytes in the mixture in 30-45 min, greatly improving the concentration of analytes and decreasing experimental time (approximately $6 \mathrm{~h}$ in the industry) [68]. However, special microfluidic injection channels can also be used. For example, Shu et al. integrated multiple PCR steps into microfluidics by preparing special continuous-flow channels. With this special device, the genes of S. enterica, L. monocytogenes, E. coli O157:H7, and S. aureus could be simultaneously amplified and detected from banana, milk, and sausage samples. The whole experiment required only $19 \mathrm{~min}$, with a detection limit as low as $10^{2}$ copies/ $\mu \mathrm{L}[69]$.

\subsubsection{Bio-Recognition Molecules}

Even if the concentration of analytes can be increased, the detection of the target in the presence of some similar components is challenging. Therefore, some biomarkers capable of specifically recognizing the analyte are required to achieve the rapid and accurate detection of the target. As shown in Figure 3, there is the high specific interaction between some surface antigen biomarkers and recognition molecules.

Antibodies are one of the most common bio-recognition molecules. Savas et al. used a biosensor-conjugated antibody on gold nanoparticles to successfully detect Salmonella from human stool samples. The fully automated microfluidic electrochemical sensor allowed Salmonella, as low as $1 \mathrm{CFU} / \mathrm{mL}$, to be sensitively and specifically detected in mixed samples by a specific reaction between the specific antibody and the antigen on the surface of the bacteria [70]. As an alternative to antibodies, aptamers are single-stranded nucleic acid molecules that are stable, easy to synthesize, and cheaper than antibodies. Aptamers can also specifically bind target molecules and can be modified with various fluorescent dyes or other labels. Wu et al. first separated and concentrated analytes from a mixed solution using the property of $\mathrm{Fe}_{3} \mathrm{O}_{4}$ magnetic nanoparticles. Next, according to the specificity of the aptamer of different bacteria, color-changing upconverting nanoparticles conjugated with different aptamers were used as a signal probe to detect three corresponding pathogenic bacteria. The color change of the multi-color upconverting nanoparticle composite indicated whether the bacteria existed in the mixture to achieve simultaneous, sensitive and selective detection [71].

Lectins can also be used as a bio-recognition molecule. Kang et al. studied different sizes of magnetic nanoparticles coated with lectins for the capture of pathogenic bacteria from mixed solutions. The result showed that magnetic nanoparticles with a radius of $250 \mathrm{~nm}$ were the most effective method for separating and detecting $S$. aureus in a mixed solution $\left(10^{2} \mathrm{CFU} / \mathrm{mL}\right)$ [72]. Another study used concanavalin A (ConA), a mannose/glucose-binding lectin that can be used to recognize lipopolysaccharides exposed to bacterial surfaces. Dao et al. combined ConA-functionalized microfluidic chips with LAMP to capture and enrich Salmonella typhimurium in urine samples $(10 \mathrm{~mL})$. 
Through this integrated system, the label-free, fast and real-time detection of Salmonella typhimurium with a concentration as low as $5 \mathrm{CFU} / \mathrm{mL}$ was completed in $100 \mathrm{~min}$ [73].

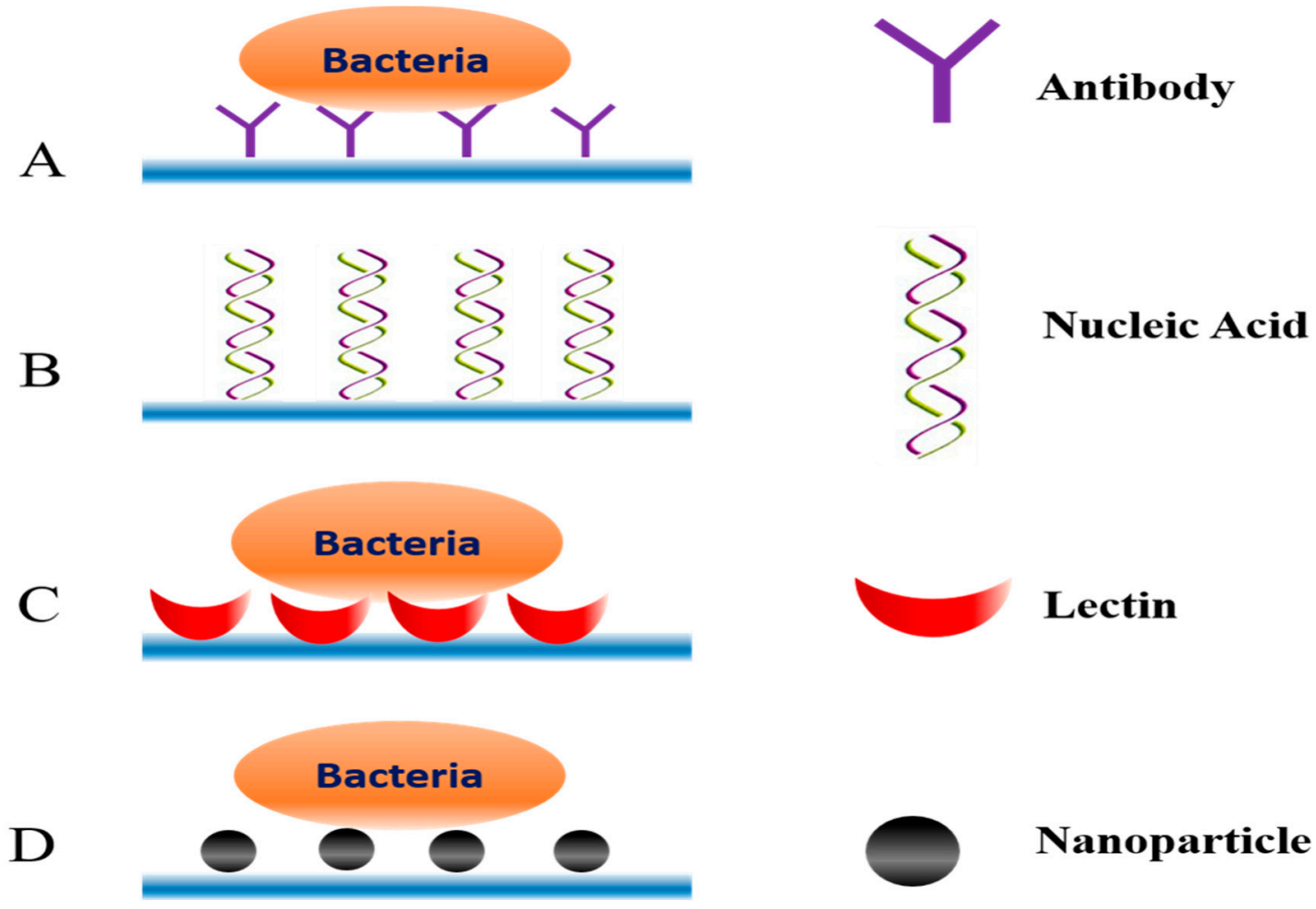

Figure 3. Schematic view of different bio-recognition elements in microfluidics. (A) Antibody; (B) Nucleic Acid; (C) Lectin; (D) Nanoparticle.

\section{Application of Microfluidic Combined with Different Technologies}

Currently, traditional technologies, such as PCR, ELISA and LAMP, are accurate and effective, but they may be costly and complicated [74,75]. Furthermore, for food or other complex environmental samples, the acquisition of the analytes may be difficult or it may be challenging to completely integrate the separation and detection processes in a single microfluidic chip [76]. In particular, if the physical and chemical properties of each component to be tested in the sample are similar, it may be difficult to simultaneously distinguish and detect various substances. The future work should aim to decrease pre-processing or to combine pre-processing steps with detection for the analysis of foodborne pathogens. The successful application mainly depends on high efficiency, high speed, and the automation of microfluidic technology, combined with different technologies, such as electrochemical biosensors, optical biosensors, immunoassays and nucleic acid-based methods [77].

\subsection{Biosensor-Based Microfluidics for the Detection of Foodborne Pathogens}

Biosensors are developed based on knowledge from the disciplines of biology, chemistry, physics, medicine, and electronic technology. A biosensor is sensitive to biological substances and can convert signals, such as the concentration and activity of analytes, into electrical signals for rapid detection [78-80]. Safavieh et al. used a microfluidic electrochemical biosensor that combined with LAMP for the detection and quantification of E. coli. There is no need of probe immobilization, and bacterial detection can be done in a single chamber without DNA extraction and purification steps. This experiment can detect and quantify bacteria to $24 \mathrm{CFU} / \mathrm{mL}$ and $8.6 \mathrm{fg} / \mu \mathrm{L}$ of DNA within $60 \mathrm{~min}$ [81]. This shows the use of biosensors in microfluidic chips may provide integrated systems with improved sensitivity and rapid and on-line detection. Biosensors include both the optical biosensors and electrochemical biosensors [82]. 


\subsubsection{Microfluidic Chips with Optical Detection}

Surface Plasmon Resonance (SPR) Biosensors

Surface plasmon resonance (SPR) is a high-sensitivity and real-time spectral analysis technique that measures the change in the refractive index of a surface material on a metal film. The application of SPR for the detection of analytes is shown in Figure 4. The advantage of SPR is that the object tested is label-free, and the method is easy and quick, allowing dynamic and real-time monitoring of the reaction $[83,84]$. At present, SPR has been used to detect pathogenic bacteria, allergens, and toxins [85].

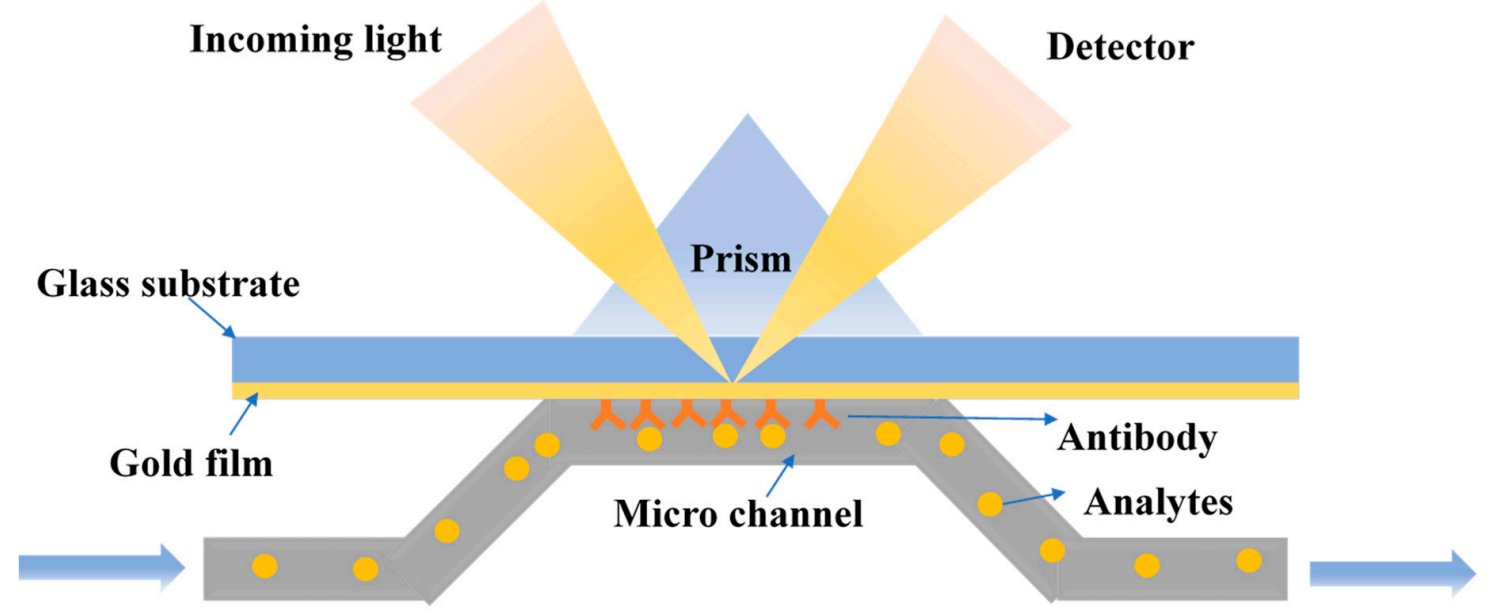

Figure 4. The principle of surface plasmon resonance detection.

Zordan et al. designed a hybrid microfluidic biochip for the detection of pathogens using SPR combined with fluorescence imaging. An array of gold spots was included in the microfluidic system to specifically capture the specific pathogens. A closed polydimethylsiloxane (PDMS) microfluidic flow chamber was used to transport and magnetically concentrate the sample to be tested. SPR and fluorescence were then used for the successful detection of E. coli O157:H7 [86]. The Zordan's group also developed a biosensor array chip to specifically detect the presence of different pathogens. In this design, the PDMS microfluidic system allowed SPR and fluorescence imaging for simultaneous, rapid, label-free, real-time and multiple detection of foodborne pathogens. Furthermore, the functionalized magnetic particles were applied to a hybrid microfluidic biochip [87]. Tokel et al. prepared a portable, low cost and multiplexed microfluidic system that used SPR to detect and quantify E. coli and S. aureus. As a result, $100 \mu \mathrm{L}$ of E. coli or S. aureus in phosphate buffered saline and peritoneal dialysis solution at a concentration of $10^{5}$ to $3.2 \times 10^{7} \mathrm{CFU} / \mathrm{mL}$ can be reliably and specifically detected within $20 \mathrm{~min}$ [88].

\section{Optical Fibre Biosensors}

Fiber-optic biosensors can selectively interact with a specific biosensor (i.e., antigen-antibody or enzymes), resulting in the production of biological or chemical information that can be converted into a transmitted light signal captured by the optical fiber, with varying light intensities, light amplitude, or phases [89]. An ideal sensor has good selectivity and high sensitivity for bacterial pathogens, pesticides, and toxins $[90,91]$. However, the spectra generated by the complexes or products formed in the experiments are similar, so the fibers are unable to be easily distinguished and detected. Therefore, the indicators or labels, such as enzymes, fluorescent substances, acid-based indicators, and lanthanide complexes are often used. Instead, optical fiber biosensors are mostly used in conjunction with various spectroscopy techniques such as absorption, fluorescence, or surface enhanced Raman spectroscopy (SERS) to improve sensitivity.

The Raman signal from molecules located near a nano-structured metallic surface and excited by visible light can be strongly enhanced, a process known as surface enhanced Raman scattering (SERS). 
SERS is widely used in the detection of foodborne pathogens. Li et al. invented a microfluidic chip with an integrated nanoporous gold disk array, a highly effective SERS substrate. The integrated system has an order of magnitude of a larger surface area than its projected disk area, corresponding to a great improvement of the Raman signal. Rhodamine was used to test the performance of the microfluidic device, showing excellent and rapid detection [92]. Mungroo et al. developed a microfluidic device with silver nanoparticles to improve the detection of pathogenic bacteria. The data analysis included homometric, principle component, and linear discriminant analyses. This platform allowed the detection and discrimination of multiple major foodborne pathogens: E. coli O157:H7, Salmonella, S. enteritidis, P. aeruginosa, L. monocytogenes, and L. innocua [93].

Gilli et al. designed a disposable plastic sensing device that utilized a total internal reflection fluorescence optical. There is no interference caused by non-specific binding or noise, and the microfluidic chip is connected with automated and sensitive customized software to realize the multiplex detection of the different targets [94].

\subsubsection{Microfluidic Chip with Electrochemical Detection}

Electrochemical biosensors use electrodes as conversion elements and immobilize bio-sensitive substances including antigens, antibodies, or enzymes onto the electrode to detect target molecules by specific bio-recognition and antigen interaction [95]. The above reactions can be transformed into electrical signals, such as capacitance, current, potential, or conductivity, to achieve the qualitative or quantitative detection of analytes, resulting in powerful tools for the detection of biological samples [96-98].

Tan et al. developed a stable PDMS microfluidic device with an impedance immunosensor by grafting modified silane and an antibody on nanoporous membranes for the specific measurement of E. coli O157:H7 and S. aureus. The difference between these bacteria was expressed by monitoring the amplitude change of the impedance spectrum before and after the bacteria captured by complimentary antibodies on the nanoporous alumina membrane, which achieved a rapid and sensitive bacterial assay of $10^{2} \mathrm{CFU} / \mathrm{mL}$ in $2 \mathrm{~h}$ [46]. Chen et al. developed a fast, sensitive and complex microfluidic device that integrated electrochemical impedance analysis and urease catalysis to measure Listeria. The bacteria cells, the modified magnetic nanoparticles (MNPs) with anti-Listeria monoclonal antibodies, anti-Listeria polyclonal antibodies, and the urease modified gold nanoparticles (AuNPs), were incubated in an integrated microfluidic chip with active mixing to form MNP-Listeria-AuNP-urease sandwich complexes. Through this platform, Listeria can be detected as low as $1.6 \times 10^{2} \mathrm{CFU} / \mathrm{mL}$ in one hour [99].

Overall, the use of online, automated, and sensitive microfluidic impedance biosensors for bacterial separation and detection is promising. To improve the effectiveness of these systems, Liu et al. integrated dielectrophoresis and electrochemical impedance into microfluidics for in-situ impedance detection of bacteria. The dielectrophoresis technique was applied to enrich trace bacteria. The microarray electrode microfluidic chips can specifically detect bacteria from microsystems. The detection limit of E. coli O157:H7 in this device was $5 \times 10^{4} \mathrm{CFU} / \mathrm{mL}$ in $6 \mathrm{~min}$ [100]. This integrated microfluidic analysis microsystem is the first step for the rapid real-time in situ detection of bacteria.

The above devices are impedance-based for the detection of foodborne pathogens. In addition, there are voltametry-based microfluidics. Safavieh et al. used LAMP in a microfluidic system for the quantitative detection of E. coli $\mathrm{O} 157: \mathrm{H} 7$ and S. aureus using the linear sweep voltametry method. The foodborne pathogens with a detection limit of $48 \mathrm{CFU} / \mathrm{mL}$ were detected in $35 \mathrm{~min}$. Unlike other electrochemical techniques, this method does not require a complex probe immobilization process, and bacterial detection can be performed in the chamber structure without the need for DNA extraction and purification steps [81].

\subsection{Immunoassay-Based Microfluidics for the Detection of Foodborne Pathogens}

The immunological methods offer high specificity, high sensitivity, and high analytical capacity based on the specific reaction between the antigen and antibody to form a complex, as shown in 
Figure 5. The immunological approaches have been used to detect bacteria, viruses, fungi, various toxins, parasites, proteins, hormones, other physiologically active substances, drug residues, and antibiotics [101]. The determination of pathogenic bacteria by immunological methods alone is prone to cross-contamination risks and negative results, and requires trained personnel. However, when combined with microfluidic technology and immunoassays, specific antigen-antibody reactions can enhance the specificity and sensitivity of microfluidic analysis. Additionally, the use of microfluidics is rapid, has low-consumption, and automated compared to traditional immunology techniques, such as ELISA, lateral flow assays (LFAs), or radioimmunoassays (RIAs), which may require long detection times, expensive reagents, or complicated procedures [102].

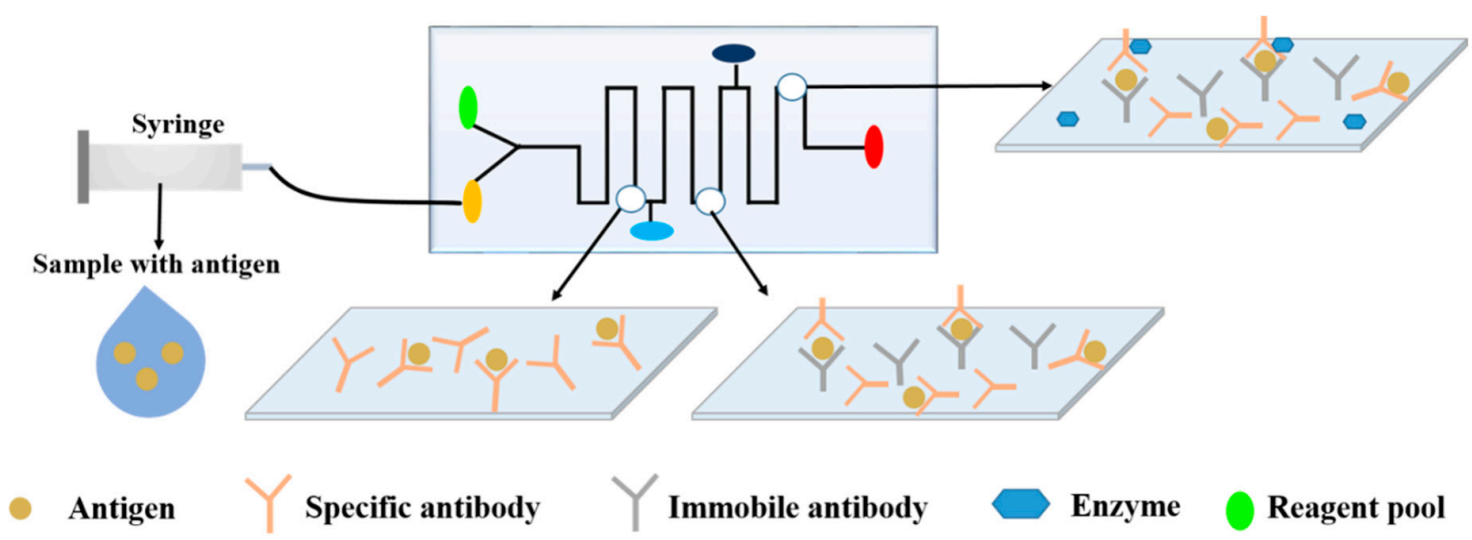

Figure 5. The basic principles of immunoassay-based microfluidics for the detection of foodborne pathogens.

\subsubsection{Enzyme-Linked Immunosorbent Assay (ELISA)}

In ELISA, a known antigen or antibody on the surface of a solid phase carrier (polystyrene microplate) is bound in an enzyme-labeled antigen-antibody reaction, and any free components in the liquid phase are washed away. This method has been applied to the effective and specific detection of pathogenic bacteria [103,104].

Thaitrong et al. designed a microfluidic sandwich ELISA for the rapid determination of plant pathogens. The microfluidic concentrator was fabricated using a microchannel, and the all reactions were in a microfluidic channel with the help of capillary force to drive the flow of the reactants [104]. Compared to traditional methods, this microfluidic system is faster, more portable, energy-efficient, and protected against sample contamination, providing a new approach for the detection of pathogens [92]. In a similar device by Wu et al. analytes were concentrated by mixing iron particles with PDMS to form an electromagnetically-driven microdevice that could be controlled by the application of a magnetic field [105], as described by Yanagisawa and Dutta [106].

\subsubsection{Immunomagnetic Fluorescence Assay (IMS)}

The IMS assay is also based on the reaction between the antigen and antibody. When the IMS assay combined with microfluidic-based technology, the performance of the IMS assay can be more highly specific and sensitive, fast, and convenient. Zhang et al. connected an optical fiber spectrometer with a microfluidic device to achieve the rapid and sensitive detection of avian influenza virus. The integrated device allowed the immunomagnetic capture, concentration, and fluorescence detection of foodborne pathogens [107]. Similarly, Kanayeva et al. combined magnetic nanoparticles, a microfluidic chip, and an interdigitated microelectrode to integrate an impedance immunosensor for the efficient separation and sensitive detection of L. monocytogenes [108].

There are several other microfluidic based immunological methods, such as lateral flow assays (LFAs) $[109,110]$ and RIAs [111]. Although the combination of immunology and microfluidics has greatly improved its performance, further improvement is possible. For example, non-specific binding 
is a problem and increased objectivity is required for result interpretation, as it can lead to wrong results and affect later experiments [112].

\subsection{Nucleic Acid-Based Microfluidics for the Detection of Foodborne Pathogens}

Nucleic acid-based methods can be used to detect a certain sequence of DNA or RNA from pathogens, using capture and detector probes (short DNA or RNA sequences). These methods can provide more specific and accurate results than the above methods. The integration of nucleic acid-based detection technology in microfluidic devices has been widely applied in various fields due to the small-volume sample requirement, fast detection time, and simple sample processing, especially for the detection of foodborne pathogens [56,113]. Nucleic acid-based detection methods include PCR, LAMP, and recombinase polymerase amplification (RPA).

\subsubsection{Polymerase Chain Reaction (PCR)}

Ganesh et al. designed an integrated microfluidic PCR system consisting of two main components: A preconcentration chamber for the immunomagnetic separation of bacterial and a PCR chamber for DNA amplification. Further, E. coli O157:H7 with the detection limit of $10^{3} \mathrm{CFU} / \mathrm{mL}$ was successfully detected by the integrated system [65]. Zhang and Wang developed an integrated microfluidic platform with silica superparamagnetic particle-based solid phase extraction for cell lysis, DNA binding, washing, elution, and PCR on a single platform [114]. The preparation, principle, and usage of specific PCR-based microfluidic chips have been described [58,59].

\subsubsection{Multiplex PCR}

Zhang et al. reported a flow-based multiplex PCR microfluidic system capable of high-throughput and rapid DNA amplification to detect foodborne pathogens. The system consisted of four reaction channels to simultaneously detect L. monocytogenes, E. coli O 157:H7, and S. enterica from food samples. Multiplex PCR with a special injection device of oscillatory-flow used only $5 \mu \mathrm{L}$ of the sample and the reaction can be completed in $13 \mathrm{~min}$, being one sixth of the time required for conventional PCR (70 min) [115]. Similarly, Shu et al. prepared a segmented continuous-flow multiplex PCR on a special spiral channel microfluidic device that consists of a disposable polytetrafluoroethylene capillary microchannel coiled on three isothermal blocks. The microfluidic device rapidly identified a variety of foodborne pathogens, including S. enterica, L. monocytogenes, E. coli O157:H7 and S. aureus. After optimizing the parameters, their genomic DNA of four bacteria were amplified simultaneously at 19 min with a minimum detection limit of $10^{2}$ copies/ $\mu \mathrm{L}$ [69].

\subsubsection{Loop-Mediated Isothermal Amplification (LAMP)}

Compared with enzyme-linked immunosorbent assays, LAMP is a rapid and specific method for nucleic acid amplification. LAMP does not require thermal denaturation, temperature cycling, electrophoresis, or ultraviolet detection, and it shows better sensitivity, specificity, cost and detection range than PCR. Additionally, LAMP does not require a complex temperature gradient regulation for high-throughput rapid detection.

Tourlousse et al. developed a cheap, portable, easy-to-use, single use polymeric microfluidic chip for the quantitative detection of different pathogens by isothermal nucleic acid amplification. The microfluidic chips were able to rapidly and quantitatively detect bacteria DNA of 10-100 genomes $/ \mu \mathrm{L}$ in $20 \mathrm{~min}$ [116]. Uddin et al. prepared a rapid, automatic and novel microfluidic compact disk platform combined with LAMP and a color sensor for the sensitive detection of different DNA concentrations for Salmonella. Furthermore, a disk platform can achieve a simultaneous detection of multiple sets of samples [117]. For simultaneous detection of complex samples, Sun et al. described an eight-chamber microfluidic chip that takes advantage of magnetic bead-based sample preparation and LAMP for the rapid quantitative detection of Salmonella in food samples. The system can measure Salmonella at concentrations of 50 cells per test within $40 \mathrm{~min}$ for rapid on-site screening of foodborne pathogens [118]. 
However, nucleic acid-based microfluidics for the detection of foodborne pathogens include RPA, a nucleic acid detection technology that allows for single-molecule nucleic acid detection at room temperature within $15 \mathrm{~min}$. This technology is truly portable and fast, with acid-based detection for analytes and low requirements for hardware equipment $[119,120]$. Other methods for pathogen detection include nuclear acid sequence-based amplification (NASBA) and nuclear acid sequence-based amplification (HAD) [121-123].

\section{Challenges and Opportunities}

Microfluidics integrates the functions of a full laboratory into a single device, including sampling, dilution, reagent addition, reaction, separation, and detection. The potential applications of microfluidics in the food industry include the detection of foodborne pathogens, but also the detection of pesticide residues, heavy metals, or food additives. Microfluidic devices require lower consumption of reagents, and provide faster screening with shorter reaction times and lower costs. Thus, microfluidic technology provides promising approaches to solve key and complex problems in food safety.

However, the application of microfluidics based on different technologies for the detection of foodborne pathogens is still in its infancy. Although some special materials and bio-recognition molecules can be used to improve the detection of targets in actual samples, there may be some non-specific binding that can influence the results of the experiment. The severity of this problem, based on the composition of the food samples and the variation of the sample pretreatment processes, is described by Li. et al. [124]. However, current analytical systems are relatively immature, so the detection of pathogenic bacteria is not yet precise [72]. Furthermore, a major challenge to be overcome is that existing microfluidic systems are complex or expensive to easily integrate into a functional system, and such ease of integration is required for convenient use in food safety. However, there are great expectations for further innovation and development of highly efficient microfluidic technologies for measuring pathogenic bacteria.

\section{Conclusions}

Food safety is closely related to human health, therefore, powerful, sensitive and effective tools are needed to ensure food safety, such as the detection of foodborne pathogens. The high selectivity, sensitivity, and efficiency of microfluidic technology can employ these devices to replace some traditional labor-intensive and slow-culture methods for the detection of pathogens in foods. However, capturing effective pathogens from complex food samples for high-throughput multiplex analysis remains inefficient. Consequently, when some traditional methods are combined with microfluidic technologies that can be more effective, the preconcentration and sample preparation steps are typically improved and simplified. This article described the incorporation of rapid detection techniques such as SPR, ELISA, PCR, and LAMP in microfluidic devices for improving the detection efficiency of foodborne pathogens.

Nevertheless, the technologies for preparing microfluidic devices and integrating microfluidics with other detection technologies are imperfect and are in the initial stages of industrialization. Therefore, further exploration and research is needed to expand the application of microfluidic technology in different industries. The authors are confident that microfluidics will be more broadly applied in multiple fields, once these problems are addressed in future studies.

Funding: This work has been supported by the National Natural Science Foundation of China (31501582), Hubei Provincial Natural Science Foundation of China (2018CFB514), Graduate Innovative Fund of Wuhan Institute of Technology (CX2018163 and CX2018167) and Innovation Cultivation Project of School of Pharmacy and Food Science, Zhuhai College of Jilin University(2018YSCP01).

Conflicts of Interest: The authors declare no conflict of interest. 


\section{References}

1. Chapman, B.; Gunter, C. Local Food Systems Food Safety Concerns. Microbiol. Spectr. 2018, 6, 34-39. [CrossRef] [PubMed]

2. Zhao, X.; Li, M.; Xu, Z. Detection of Foodborne Pathogens by Surface Enhanced Raman Spectroscopy. Front. Microbiol. 2018, 9, 1236. [CrossRef] [PubMed]

3. Jones, T.F.; Yackley, J. Foodborne Disease Outbreaks in the United States: A Historical Overview. Foodborne Pathog. Dis. 2018, 15, 11-15. [CrossRef] [PubMed]

4. Parisi, A.; Crump, J.A.; Glass, K.; Howden, B.P.; Furuya-Kanamori, L.; Vilkins, S.; Gray, D.J.; Kirk, M.D. Health Outcomes from Multidrug-Resistant Salmonella Infections in High-Income Countries: A Systematic Review and Meta-Analysis. Foodborne Pathog. Dis. 2018, 15, 428-436. [CrossRef] [PubMed]

5. Zhao, X.; Lin, C.W.; Wang, J.; Oh, D.H. Advances in rapid detection methods for foodborne pathogens. J. Microbiol. Biotechnol. 2014, 24, 297. [CrossRef] [PubMed]

6. Liu, J.Y.; Zhou, R.; Li, L.; Peters, B.M.; Li, B.; Lin, C.W.; Peters, B.M.; Chuang, T.L.; Chen, D.Q.; Zhao, X.H.; et al. Viable but non-culturable state and toxin gene expression of enterohemorrhagic Escherichia coli $\mathrm{O} 157$ under cryopreservation. Res. Microbiol. 2017, 168, 188-193. [CrossRef] [PubMed]

7. Torgerson, P.R.; Devleesschauwer, B.; Praet, N.; Speybroeck, N.; Willingham, A.L.; Kasuga, F.; Rokni, M.B.; Zhou, X.N.; Fèvre, E.M.; Sripa, B.; et al. World Health Organization Estimates of the Global and Regional Disease Burden of 11 Foodborne Parasitic Diseases, 2010: A Data Synthesis. PLoS Med. 2015, 12, e1001920. [CrossRef]

8. Yang, S.C.; Lin, C.H.; Aljuffali, I.A.; Fang, J.Y. Current pathogenic Escherichia coli foodborne outbreak cases and therapy development. Arch. Microbiol. 2017, 199, 811-825. [CrossRef] [PubMed]

9. Zhao, X.H.; Wei, C.J.; Zhong, J.L.; Jin, S.W. Research advance in rapid detection of foodborne Staphylococcus aureus. Biotechnol. Biotechnol. Equip. 2016, 30, 827-833. [CrossRef]

10. Umesha, S.; Manukumar, H.M. Advanced Molecular Diagnostic Techniques for Detection of Food-borne Pathogens: Current Applications and Future Challenges. Crit. Rev. Food Sci. Nutr. 2018, 58, 84-104. [CrossRef]

11. Wei, C.J.; Zhong, J.L.; Hu, T.; Zhao, X.H. Simultaneous detection of Escherichia coli O157:H7, Staphylococcus aureus and Salmonella by multiplex PCR in milk. 3 Biotech 2018, 8, 76. [CrossRef] [PubMed]

12. Zhao, X.; Zhao, F.; Wang, J.; Zhong, N. Biofilm formation and control strategies of foodborne pathogens: Food safety perspectives. RSC Adv. 2017, 7, 36670-36683. [CrossRef]

13. Zhong, J.; Zhao, X. Isothermal amplification technologies for the detection of foodborne pathogens. Food Anal. Methods 2018, 11, 1543-1560. [CrossRef]

14. Zhao, X.; Zhong, J.; Wei, C.; Lin, C.W.; Ding, T. Current perspectives on viable but non-culturable state in foodborne pathogens. Front. Microbiol. 2017, 8, 580. [CrossRef] [PubMed]

15. Holmes, D.; Gawad, S. The application of microfluidics in biology. Methods Mol. Biol. 2010, 583, 55-80. [PubMed]

16. Yujie, L.I.; Huo, Y.; Di, L.I.; Tang, X.; Shi, F.; Wang, C. Technology, application and development of microfluidics. J. Hebei Univ. Sci. Technol. 2014, 35, 11.

17. Wen, N.; Zhao, Z.; Fan, B.; Chen, D.; Men, D.; Wang, J.; Chen, J. Development of Droplet Microfluidics Enabling High-Throughput Single-Cell Analysis. Molecules 2016, 21, 881. [CrossRef] [PubMed]

18. Wang, K.-K.; Ke, Y.; Jun, Z.; Can-Can, Z.; Ling, Z.; Yong, L. Rapid Detection of Hepatitis B Virus Nucleic Acid Based on Microfluidic Chip Using Fluorescence Quantitative PCR. J. Anal. Sci. 2018, 34, 11-15.

19. Wang, C.; Madiyar, F.; Yu, C.; Li, J. Detection of extremely low concentration waterborne pathogen using a multiplexing self-referencing SERS microfluidic biosensor. J. Biol. Eng. 2017, 11, 9. [CrossRef]

20. Wan, L.; Chen, T.; Gao, J.; Dong, C.; Wong, A.H.; Jia, Y.; Mak, P.; Deng, C.X.; Martins, R.P. A digital microfluidic system for loop-mediated isothermal amplification and sequence specific pathogen detection. Sci. Rep. 2017, 7, 14586. [CrossRef]

21. Jokerst, J.C.; Adkins, J.A.; Bisha, B.; Mentele, M.M.; Goodridge, L.D.; Henry, C.S. Development of a Paper-Based Analytical Device for Colorimetric Detection of Select Foodborne Pathogens. Anal. Chem. 2012, 84, 2900-2907. [CrossRef] [PubMed]

22. Long, H.; Bao, L.J.; Habeeb, A.A.; Lu, P.X. Effects of doping concentration on the surface plasmonic resonances and optical nonlinearities in AGZO nano-triangle arrays. Opt. Quantum Electron. 2017, 49, 345. [CrossRef] 
23. Sun, Y.; Liu, D.M.; Lu, P.; Sun, Q.Z.; Yang, W.; Wang, S.; Liu, L.; Zhang, J.S. Dual-Parameters Optical Fiber Sensor with Enhanced Resolution Using Twisted MMF Based on SMS Structure. IEEE Sens. J. 2017, 17, 3045-3051. [CrossRef]

24. Squires, T.M.; Quake, S.R. Microfluidics: Fluid physics at the nanoliter scale. Rev. Mod. Phys. 2005, 77, 977-1026. [CrossRef]

25. Whitesides, G.M. The origins and the future of microfluidics. Nature 2006, 442, 368-373. [CrossRef] [PubMed]

26. Weng, X.; Neethirajan, S. Paper-based microfluidic aptasensor for food safety. J. Food Saf. 2017, 38 , e12412. [CrossRef]

27. Xu, J.; Kawano, H.; Liu, W.W.; Hanada, Y.; Lu, P.X.; Miyawaki, A.; Midorikawa, K.; Sugioka, K. Controllable alignment of elongated microorganisms in 3D microspace using electrofluidic devices manufactured by hybrid femtosecond laser microfabrication. Microsyst. Nanoeng. 2017, 3, 16078. [CrossRef] [PubMed]

28. Huang, Z.Q.; He, X.Q.; Liew, K.M. A sensitive interval of imperfect interface parameters based on the analysis of general solution for anisotropic matrix containing an elliptic inhomogeneity. Int. J. Solids Struct. 2015, 73-74, 67-77. [CrossRef]

29. Hou, M.; Wang, Y.; Liu, S.; Guo, J.; Li, Z.; Lu, P. Sensitivity-Enhanced Pressure Sensor with Hollow-Core Photonic Crystal Fiber. J. Lightwave Technol. 2014, 32, 4637-4641.

30. Manz, A.; Graber, N.; Widmer, H.M. Miniaturized total chemical analysis systems: A novel concept for chemical sensing. Sens. Actuators B Chem. 1990, 1, 244-248. [CrossRef]

31. Manz, A.; Harrison, D.J.; Verpoorte, E.M.J.; Fettinger, J.C.; Paulus, A.; Lüdi, H.; Widmer, H.M. Planar chips technology for miniaturization and integration of separation techniques into monitoring systems: Capillary electrophoresis on a chip. J. Chromatogr. A 1992, 593, 253-258. [CrossRef]

32. Woolley, A.T.; Mathies, R.A. Ultra-high-speed DNA sequencing using capillary electrophoresis chips. Anal. Chem. 1995, 67, 3676-3680. [CrossRef] [PubMed]

33. Woolley, A.T.; Hadley, D.; Landre, P.; Demello, A.J.; Mathies, R.A.; Northrup, M.A. Functional integration of PCR amplification and capillary electrophoresis in a microfabricated DNA analysis device. Anal. Chem. 1996, 68, 4081-4086. [CrossRef] [PubMed]

34. Brahmasandra, S.N.; Johnson, B.N.; Webster, J.R.; Burke, D.T.; Mastrangelo, C.H.; Burns, M.A. On-chip DNA band detection in microfabricated separation systems. Proc. Spie-Int. Soc. Opt. Eng. 1998, 3515, $242-251$.

35. Anderson, J.R.; Chiu, D.T.; Jackman, R.J.; Cherniavskaya, O.; Mcdonald, J.C.; Wu, H.; Whitesides, S.H.; Whitesides, G.M. Fabrication of topologically complex three-dimensional microfluidic systems in PDMS by rapid prototyping. Anal. Chem. 2000, 72, 3158-3164. [CrossRef] [PubMed]

36. Ghaemmaghami, A.M.; Hancock, M.J.; Harrington, H.; Kaji, H.; Khademhosseini, A. Biomimetic tissues on a chip for drug discovery. Drug Discov. Today 2012, 17, 173-181. [CrossRef]

37. Marre, S.; Jensen, K.F. Synthesis of micro and nanostructures in microfluidic systems. Chem. Soc. Rev. 2010, 39, 1183-1202. [CrossRef] [PubMed]

38. Mu, X.; Zheng, W.; Sun, J.; Zhang, W.; Jiang, X. Microfluidics for Manipulating Cells. Small 2013, 9, 9-21. [CrossRef]

39. Zhao, D.; Liu, W.W.; Ke, S.L.; Liu, Q.J. Large lateral shift in complex dielectric multilayers with nearly parity-time symmetry. Opt. Quantum Electron. 2018, 50, 323. [CrossRef]

40. Chuang, T.L.; Chang, C.C.; Chu-Su, Y.; Wei, S.C.; Zhao, X.H.; Hsueh, P.R.; Lin, C.W. Disposable surface plasmon resonance aptasensor with membranebased sample handling design for quantitative interferon-gamma detection. Lab Chip 2014, 14, 2968-2977. [CrossRef]

41. Atsushi, K.; Akiko, I.; Tamotsu, Y.; Yoshiaki, U.; Eiichi, T.; Yuzuru, T. Highly sensitive elemental analysis for $\mathrm{Cd}$ and $\mathrm{Pb}$ by liquid electrode plasma atomic emission spectrometry with quartz glass chip and sample flow. Anal. Chem. 2011, 83, 9424-9430.

42. Francisca, A.; Neha, S.; Mohammad-Ali, S.; Dongfei, L.; Bárbara, H.B.; Makila, E.M.; Jarno, J.S.; Jouni, T.H.; Pedro, L.G.; Bruno, S.; et al. Microfluidic Assembly of a Multifunctional Tailorable Composite System Designed for Site Specific Combined Oral Delivery of Peptide Drugs. Acs Nano 2015, 9, 8291-8302.

43. Xuan, T.V.; Stockmann, R.; Wolfrum, B.; Offenhäusser, A.; Ingebrandt, S. Fabrication and application of a microfluidic-embedded silicon nanowire biosensor chip. Phys. Status Solidi 2010, 207, 850-857.

44. Zhang, H.; Dongfei, L.; Mohammad-Ali, S.; Ermei, M.K.; Bárbara, H.B.; Jarno, S.; Hirvonen, J.; Santos, H.A. Fabrication of a multifunctional nano-in-micro drug delivery platform by microfluidic templated encapsulation of porous silicon in polymer matrix. Adv. Mater. 2014, 26, 4497-4503. [CrossRef] [PubMed] 
45. Crabtree, H.J.; Morrissey, Y.C.; Taylor, B.J.; Liang, T.; Johnstone, R.W.; Stickel, A.J.; Manage, P.; Atrazhev, A.; Backhouse, C.J.; Pilarski, L.M. Inhibition of on-chip PCR using PDMS-glass hybrid microfluidic chips. Microfluid. Nanofluid. 2012, 13, 383-398. [CrossRef]

46. Tan, F.; Leung, P.H.M.; Liu, Z.B.; Zhang, Y.; Xiao, L.; Ye, W.; Zhang, X.; Yi, L.; Yang, M. A PDMS microfluidic impedance immunosensor for E. coli O157:H7 and Staphylococcus aureus detection via antibody-immobilized nanoporous membrane. Sens. Actuators B Chem. 2011, 159, 328-335. [CrossRef]

47. Al-Shehri, S.; Palitsin, V.; Webb, R.P.; Grime, G.W. Fabrication of three-dimensional SU-8 microchannels by proton beam writing for microfluidics applications: Fluid flow characterisation. Nucl. Instrum. Methods Phys. Res. B 2015, 348, 223-228. [CrossRef]

48. Dy, A.J.; Cosmanescu, A.; Sluka, J.; Glazier, J.A.; Stupack, D.; Amarie, D. Fabricating microfluidic valve master molds in SU-8 photoresist. J. Micromech. Microeng. 2014, 24, 057001. [CrossRef]

49. Floquet, C.F.A.; Sieben, V.J.; Milani, A.; Joly, E.P.; Ogilvie, I.R.G.; Morgan, H.; Mowlem, M.C. Nanomolar detection with high sensitivity microfluidic absorption cells manufactured in tinted PMMA for chemical analysis. Talanta 2011, 84, 235-239. [CrossRef]

50. Wu, N.; Zhu, Y.G.; Brown, S.; Oakeshott, J.; Peat, T.; Surjadi, R.; Easton, C.; Leech, P.W.; Sexton, B.A. A PMMA microfluidic droplet platform for in Vitro protein expression using crude E. Coli S30 extract. Lab Chip 2009, 9, 3391-3398. [CrossRef]

51. Stojkovič, G.; Krivec, M.; Vesel, A.; Marinšek, M.; Žnidaršič-Plazl, P. Surface cell immobilization within perfluoroalkoxy microchannels. Appl. Surf. Sci. 2014, 320, 810-817. [CrossRef]

52. Detlev, B.; Alfred, D.; Frank, K.; Martin, L. Poly (vinyl alcohol)-coated microfluidic devices for high-performance microchip electrophoresis. Electrophoresis 2015, 23, 3567-3573.

53. Huang, K.W.; Wu, Y.C.; Lee, J.A.; Chiou, P.Y. Microfluidic integrated optoelectronic tweezers for single-cell preparation and analysis. Lab Chip 2013, 13, 3721-3727. [CrossRef] [PubMed]

54. Hong, B.; Xue, P.; Wu, Y.; Bao, J.; Chuah, Y.J.; Kang, Y. A concentration gradient generator on a paper-based microfluidic chip coupled with cell culture microarray for high-throughput drug screening. Biomed. Microdevices 2016, 18, 21. [CrossRef] [PubMed]

55. Li, W.L.; Wu, A.; Li, Z.C.; Zhang, G.; Yu, W.Y. A new calibration method between an optical sensor and a rotating platform in turbine blade inspection. Meas. Sci. Technol. 2017, 28, 035009. [CrossRef]

56. Zeng, D.; Chen, Z.; Jiang, Y.; Xue, F.; Li, B. Advances and Challenges in Viability Detection of Foodborne Pathogens. Front. Microbiol. 2016, 7, 1833. [CrossRef]

57. Zhang, R.; Hai-Qing, G.; Xudong, Z.; Chaoping, L.; Chunchau, S. A microfluidic liquid phase nucleic acid purification chip to selectively isolate DNA or RNA from low copy/single bacterial cells in minute sample volume followed by direct on-chip quantitative PCR assay. Anal. Chem. 2013, 85, 1484-1491. [CrossRef]

58. Wu, J.; Kodzius, R.; Cao, W.; Wen, W. Extraction, amplification and detection of DNA in microfluidic chip-based assays. Microchim. Acta 2014, 181, 1611-1631. [CrossRef]

59. Tachibana, H.; Saito, M.; Shibuya, S.; Tsuji, K.; Miyagawa, N.; Yamanaka, K.; Tamiya, E. On-chip quantitative detection of pathogen genes by autonomous microfluidic PCR platform. Biosens. Bioelectron. 2015, 74, 725-730. [CrossRef]

60. Wang, Y.; Jianfeng, P.; Zunzhong, Y.; Jian, W.; Yibin, Y. Impedimetric immunosensor based on gold nanoparticles modified graphene paper for label-free detection of Escherichia coli O157:H7. Biosens. Bioelectron. 2013, 4, 492-498. [CrossRef]

61. Cate, D.M.; Adkins, J.A.; Mettakoonpitak, J.; Henry, C.S.; Chem, A. Recent Developments in Paper-Based Microfluidic Devices. Anal. Chem. 2015, 87, 19-41. [CrossRef] [PubMed]

62. Liu, C.C.; Wang, Y.N.; Fu, L.M.; Chen, K.L. Microfluidic paper-based chip platform for benzoic acid detection in food. Food Chem. 2018, 249, 162-167. [CrossRef] [PubMed]

63. Wang, M.F.; Juan, H.U.; Zheng, G.; Zhao, G.H. Application of microfluidic chip in food safety analysis. Sci. Technol. Food Ind. 2011, 32, 401-404.

64. Zheng, Y.; Mao, S.; Liu, S.; Wong, S.H.; Wang, Y.W. Normalized Relative RBC-Based Minimum Risk Bayesian Decision Approach for Fault Diagnosis of Industrial Process. IEEE Trans. Ind. Electron. 2016, 63, 7723-7732. [CrossRef]

65. Ganesh, I.; Tran, B.M.; Kim, Y.; Kim, J.; Cheng, H.; Lee, N.Y.; Park, S. An integrated microfluidic PCR system with immunomagnetic nanoparticles for the detection of bacterial pathogens. Biomed. Microdevices 2016, 18, 116. [CrossRef] [PubMed] 
66. Oh, S.J.; Park, B.H.; Choi, G.; Seo, J.H.; Jung, J.H.; Choi, J.S.; Kim, D.H.; Seo, T.S. Fully automated and colorimetric foodborne pathogen detection on an integrated centrifugal microfluidic device. Lab Chip 2016, 16, 1917-1926. [CrossRef]

67. Sayad, A.; Ibrahim, F.; Mukim, S.U.; Cho, J.; Madou, M.; Thong, K.L. A microdevice for rapid, monoplex and colorimetric detection of foodborne pathogens using a centrifugal microfluidic platform. Biosens. Bioelectron. 2017, 100, 96-104. [CrossRef]

68. Li, X.; Ximenes, E.; Amalaradjou, M.A.; Vibbert, H.B.; Foster, K.; Jones, J.; Liu, X.Y.; Bhunia, A.K.; Ladisch, M.R. Rapid sample processing for detection of food-borne pathogens via cross-flow microfiltration. Appl. Environ. Microbiol. 2013, 79, 7048-7054. [CrossRef]

69. Shu, B.; Zhang, C.; Xing, D. Segmented continuous-flow multiplex polymerase chain reaction microfluidics for high-throughput and rapid foodborne pathogen detection. Anal. Chim. Acta 2014, 826, 51-60. [CrossRef]

70. Savas, S.; Ersoy, A.; Gulmez, Y.; Kilic, S.; Levent, B.; Altintas, Z. Nanoparticle Enhanced Antibody and DNA Biosensors for Sensitive Detection of Salmonella. Materials 2018, 11, 1541. [CrossRef]

71. Wu, S.; Duan, N.; Shi, Z.; Fang, C.; Wang, Z. Simultaneous aptasensor for multiplex pathogenic bacteria detection based on multicolor upconversion nanoparticles labels. Anal. Chem. 2014, 86, 3100-3107. [CrossRef] [PubMed]

72. Kang, J.H.; Um, E.; Diaz, A.; Driscoll, H.; Rodas, M.J.; Domansky, K.; Rodas, M.J.; Watters, A.L.; Super, M.; Stone, H.A.; et al. Optimization of Pathogen Capture in Flowing Fluids with Magnetic Nanoparticles. Small 2015, 11, 5657-5666. [CrossRef] [PubMed]

73. Dao, T.N.T.; Yoon, J.; Jin, C.E.; Koo, B.; Han, K.; Yong, S.; Lee, T.Y. Rapid and Sensitive Detection of Salmonella based on Microfluidic Enrichment with a Label-free Nanobiosensing Platform. Sens. Actuators B Chem. 2017, 262, 588-594. [CrossRef]

74. Deshmukh, R.A.; Joshi, K.; Bhand, S.; Roy, U. Recent developments in detection and enumeration of waterborne bacteria: A retrospective minireview. Microbiologyopen 2016, 5, 901-922. [CrossRef] [PubMed]

75. Law, J.W.; Ab Mutalib, N.S.; Chan, K.G.; Lee, L.H. Rapid methods for the detection of foodborne bacterial pathogens: Principles, applications, advantages and limitations. Front. Microbiol. 2015, 5, 770. [CrossRef] [PubMed]

76. Ríos, Á.; Zougagh, M. Modern qualitative analysis by miniaturized and microfluidic systems. Trends Anal. Chem. 2015, 69, 105-113. [CrossRef]

77. Kant, K.; Shahbazi, M.A.; Dave, V.P.; Ngo, T.A.; Chidambara, V.A.; Linh, Q.T.; Dang, D.B.; Anders, W. Microfluidic devices for sample preparation and rapid detection of foodborne pathogens. Biotechnol. Adv. 2018, 36, 1003-1024. [CrossRef]

78. Chi, L.W.; Olivo, M. Surface Plasmon Resonance Imaging Sensors: A Review. Plasmonics 2014, 9, 809-824.

79. Lee, H.; Xu, L.; Koh, D.; Nyayapathi, N.; Oh, K.W. Various on-chip sensors with microfluidics for biological applications. Sensors 2014, 14, 17008-17036. [CrossRef]

80. Liu, S.H.; Tian, J.; Liu, N.L.; Lu, P.X. Temperature Insensitive Liquid Level Sensor Based on Antiresonant Reflecting Guidance in Silica Tube. J. Lightwave Technol. 2016, 34, 5239-5243. [CrossRef]

81. Safavieh, M.; Ahmed, M.U.; Tolba, M.; Zourob, M. Microfluidic electrochemical assay for rapid detection and quantification of Escherichia coli. Biosens. Bioelectron. 2012, 31, 523-528. [CrossRef] [PubMed]

82. Narsaiah, K.; Jha, S.N.; Bhardwaj, R.; Sharma, R.; Kumar, R. Optical biosensors for food quality and safety assurance-a review. J. Food Sci. Technol. 2012, 49, 383-406. [CrossRef] [PubMed]

83. Li, Y.; Liu, X.; Lin, Z. Recent developments and applications of surface plasmon resonance biosensors for the detection of mycotoxins in foodstuffs. Food Chem. 2012, 132, 1549-1554. [CrossRef] [PubMed]

84. Wang, D.S.; Fan, S.K. Microfluidic Surface Plasmon Resonance Sensors: From Principles to Point-of-Care Applications. Sensors 2016, 16, 1175. [CrossRef] [PubMed]

85. Pennacchio, A.; Ruggiero, G.; Staiano, M.; Piccialli, G.; Oliviero, G.; Lewkowicz, A.; Synak, A.; Bojarski, P.; D'Auriaa, S. A surface plasmon resonance based biochip for the detection of patulin toxin. Opt. Mater. 2014, 36, 1670-1675. [CrossRef]

86. Zordan, M.D.; Grafton, M.M.G.; Acharya, G.; Reece, L.M.; Cooper, C.L.; Aronson, A.I.; Park, K.; Leary, J.F. Detection of pathogenic E. coli O157:H7 by a hybrid microfluidic SPR and molecular imaging cytometry device. Cytom. Part A 2010, 75, 155-162. 
87. Zordan, M.D.; Grafton, M.M.G.; Acharya, G.; Reece, L.M.; Aronson, A.I.; Park, K.; Leary, J.F. A microfluidic-based hybrid SPR/molecular imaging biosensor for the multiplexed detection of foodborne pathogens. Proc. Spie-Int. Soc. Opt. Eng. 2009, 7167, 1-10.

88. Tokel, O.; Yildiz, U.H.; Inci, F.; Durmus, N.G.; Ekiz, O.O.; Turker, B.; Cetin, C.; Rao, S.; Sridhar, K.; Natarajan, N.; et al. Portable Microfluidic Integrated Plasmonic Platform for Pathogen Detection. Sci. Rep. 2015, 5, 9152. [CrossRef] [PubMed]

89. Reig, B.; Bardinal, V.; Camps, T.; Doucet, J.B. A miniaturized VCSEL-based system for optical sensing in a microfluidic channel. Sensors 2012, 23, 1-4.

90. Ohk, S.H.; Koo, O.K.; Sen, T.; Yamamoto, C.M.; Bhunia, A.K. Antibody-aptamer functionalized fibre-optic biosensor for specific detection of Listeria monocytogenes from food. J. Appl. Microbiol. 2010, 109, 808-817. [CrossRef] [PubMed]

91. Zhou, W.; Zhang, W.; Wang, Z.; Liu, T.; Zhang, Y. Progress on fiber-optic evanescent wave biosensor technique in food safety detection. J. Food Saf. Qual. 2014, 5, 3971-3974.

92. Li, M.; Zhao, F.; Zeng, J.; Qi, J.; Lu, J.; Shih, W.C. Microfluidic surface-enhanced Raman scattering sensor with monolithically integrated nanoporous gold disk arrays for rapid and label-free biomolecular detection. J. Biomed. Opt. 2014, 19, 111611. [CrossRef] [PubMed]

93. Mungroo, N.A.; Oliveira, G.; Neethirajan, S. SERS based point-of-care detection of food-borne pathogens. Microchim. Acta 2016, 183, 697-707. [CrossRef]

94. Gilli, E. Optical biosensor system with integrated microfluidic sample preparation and TIRF based detection. Proc. Spie-Int. Soc. Opt. Eng. 2013, 8774, 140-144.

95. Setterington, E.B.; Alocilja, E.C. Electrochemical Biosensor for Rapid and Sensitive Detection of Magnetically Extracted Bacterial Pathogens. Biosensors 2012, 2, 15-31. [CrossRef]

96. Campuzano, S.; Yanez-Sedeno, P.; Pingarron, J.M. Molecular Biosensors for Electrochemical Detection of Infectious Pathogens in Liquid Biopsies: Current Trends and Challenges. Sensors 2017, 17, 2533. [CrossRef]

97. Dong, S.; Zhou, J.; Hui, D.; Pang, X.; Wang, Q.; Zhang, S.; Wang, L. Interaction between edge dislocations and amorphous interphase in carbon nanotubes reinforced metal matrix nanocomposites incorporating interface effect. Int. J. Solids Struct. 2014, 51, 1149-1163. [CrossRef]

98. Ligaj, M.; Tichoniuk, M.; Gwiazdowska, D.; Filipiak, M. Electrochemical DNA biosensor for the detection of pathogenic bacteria Aeromonas hydrophila. Electrochim. Acta 2014, 128, 67-74. [CrossRef]

99. Chen, Q.; Wang, D.; Cai, G.; Xiong, Y.; Li, Y.; Wang, M.; Hou, H.; Lin, J. Fast and sensitive detection of foodborne pathogen using electrochemical impedance analysis, urease catalysis and microfluidics. Biosens. Bioelectron. 2016, 86, 770-776. [CrossRef]

100. Liu, H.T.; Wen, Z.Y.; Xu, Y.; Shang, Z.G.; Peng, J.L.; Tian, P. An integrated microfluidic analysis microsystems with bacterial capture enrichment and in-situ impedance detection. Mod. Phys. Lett. B 2017, 31, 196-199. [CrossRef]

101. Wang, X.; Niessner, R.; Tang, D.; Knopp, D. Nanoparticle-based immunosensors and immunoassays for aflatoxins. Anal. Chim. Acta 2016, 912, 10-23. [CrossRef] [PubMed]

102. Zhu, L.; Jing, H.; Cao, X.; Huang, K.; Luo, Y.; Xu, W. Development of a double-antibody sandwich ELISA for rapid detection of Bacillus Cereus in food. Sci. Rep. 2016, 6, 16092. [CrossRef] [PubMed]

103. Rasooly, A.; Bruck, H.A.; Kostov, Y. An ELISA Lab-on-a-Chip (ELISA-LOC). Humana Press 2013, 949, 451-471.

104. Thaitrong, N.; Charlermroj, R.; Himananto, O.; Seepiban, C.; Karoonuthaisiri, N. Implementation of microfluidic sandwich ELISA for superior detection of plant pathogens. PLoS ONE 2013, 8, e83231. [CrossRef] [PubMed]

105. Wu, J.H.; Ma, Y.D.; Chung, Y.D.; Lee, G.B. An integrated microfluidic system for dual aptamer assay utilizing magnetic-composite-membranes. IEEE Int. Conf. Nano/Micro Eng. Mol. Syst. 2017, 4, 438-441.

106. Yanagisawa, N.; Dutta, D. Enhancement in the Sensitivity of Microfluidic Enzyme-Linked Immunosorbent Assays through Analyte Preconcentration. Anal. Chem. 2012, 84, 7029. [CrossRef] [PubMed]

107. Zhang, R.Q.; Liu, S.L.; Zhao, W.; Zhang, W.P.; Yu, X.; Li, Y.; Li, A.J.; Pang, D.W.; Zhang, Z.L. A Simple Point-of-Care Microfluidic Immunomagnetic Fluorescence Assay for Pathogens. Anal. Chem. 2013, 85, 2645-2651. [CrossRef]

108. Kanayeva, D.A.; Wang, R.; Rhoads, D.; Erf, G.F.; Slavik, M.F.; Tung, S.; Li, Y. Efficient separation and sensitive detection of Listeria monocytogenes using an impedance immunosensor based on magnetic nanoparticles, a microfluidic chip, and an interdigitated microelectrode. J. Food Prot. 2012, 75, 1951-1959. [CrossRef] 
109. Dector, A.; Galindo-De-La-Rosa, J.; Amaya-Cruz, D.M.; Ortíz-Verdín, A.; Guerra-Balcázar, M.; Olivares-Ramírez, J.M.; Arriaga, L.G.; Ledesma-García, J. Towards autonomous lateral flow assays: Paper-based microfluidic fuel cell inside an HIV-test using a blood sample as fuel. Int. J. Hydrog. Energy 2017, 42, 29-32. [CrossRef]

110. Hsieh, H.; Dantzler, J.; Weigl, B. Analytical Tools to Improve Optimization Procedures for Lateral Flow Assays. Diagnostics 2017, 7, 29. [CrossRef]

111. Doller, C.; Jakubik, J. Direct solid-phase radioimmunoassay for the detection of Aujeszky's disease antibodies. Zent. Bakteriol. A 1980, 247, 1-7.

112. Yao, L.; Wang, L.; Huang, F.; Cai, G.; Xi, X.; Lin, J. A microfluidic impedance biosensor based on immunomagnetic separation and urease catalysis for continuous-flow detection of E. coli O157:H7. Sens. Actuators B Chem. 2018, 259, 2657. [CrossRef]

113. Mangal, M.; Bansal, S.; Sharma, S.K.; Gupta, R.K. Molecular Detection of Food Borne Pathogens: A Rapid and Accurate Answer to Food Safety. Crit. Rev. Food Sci. Nutr. 2016, 56, 1568-1584. [CrossRef] [PubMed]

114. Zhang, Y.; Wang, T.H. An automated all-in-one microfludic device for parallel solid phase DNA extraction and droplet-inoil PCR analysis. IEEE Int. Conf. Micro Electro Mech. Syst. 2010, 9, 971-974.

115. Zhang, C.; Wang, H.; Xing, D. Multichannel oscillatory-flow multiplex PCR microfluidics for high-throughput and fast detection of foodborne bacterial pathogens. Biomed. Microdevices 2011, 13, 885. [CrossRef]

116. Tourlousse, D.M.; Ahmad, F.; Stedtfeld, R.D.; Seyrig, G.; Tiedje, J.M.; Hashsham, S.A. A polymer microfluidic chip for quantitative detection of multiple water- and foodborne pathogens using real-time fluorogenic loop-mediated isothermal amplification. Biomed. Microdevices 2012, 14, 769-778. [CrossRef] [PubMed]

117. Uddin, S.M.; Ibrahim, F.; Sayad, A.A.; Thiha, A.; Pei, K.X.; Mohktar, M.S.; Hashim, U.; Cho, J.M.; Thong, K.L. A portable automatic endpoint detection system for amplicons of loop mediated isothermal amplification on microfluidic compact disk platform. Sensors 2015, 15, 5376-5389. [CrossRef]

118. Sun, Y.; Quyen, T.L.; Hung, T.Q.; Chin, W.H.; Wolff, A.; Bang, D.D. A lab-on-a-chip system with integrated sample preparation and loop-mediated isothermal amplification for rapid and quantitative detection of Salmonella spp. in food samples. Lab Chip 2015, 15, 1898-1904. [CrossRef]

119. Lutz, S.; Weber, P.; Focke, M.; Faltin, B.; Hoffmann, J.; Müller, C.; Mark, D.; Roth, G.; Munday, P.; Armes, N.; et al. Microfluidic lab-on-a-foil for nucleic acid analysis based on isothermal recombinase polymerase amplification (RPA). Lab Chip 2010, 10, 887-893. [CrossRef]

120. Tortajada-Genaro, L.A.; Santiago-Felipe, S.; Amasia, M.; Russom, A.; Maquieira, Á. Isothermal solid-phase recombinase polymerase amplification on microfluidic digital versatile discs (DVDs). RSC Adv. 2015, 5, 29987-29995. [CrossRef]

121. Mauk, M.G.; Liu, C.; Song, J.; Bau, H.H. Integrated Microfluidic Nucleic Acid Isolation, Isothermal Amplification, and Amplicon Quantification. Microarrays 2015, 4, 474-489. [CrossRef] [PubMed]

122. Pang, B.; Fu, K.; Liu, Y.; Ding, X.; Hu, J.; Wu, W.; Xu, K.; Song, X.L.; Wang, J.; Mu, Y.; et al. Development of a self-priming PDMS/paper hybrid microfluidic chip using mixed-dye-loaded loop-mediated isothermal amplification assay for multiplex foodborne pathogens detection. Anal. Chim. Acta 2018, 1040, 81-89. [CrossRef] [PubMed]

123. Zhong, J.L.; Zhao, X.H. Detection of viable but non-culturable Escherichia coli O157:H7 by PCR in combination with propidium monoazide. 3 Biotech 2017, 8, 28. [CrossRef] [PubMed]

124. Li, M.F.; Li, L.M.; Liu, R.Y. Application of paper based microfluidic chip technology in food safety detection. J. Food Saf. Qual. 2018, 38, e12412.

(C) 2019 by the authors. Licensee MDPI, Basel, Switzerland. This article is an open access article distributed under the terms and conditions of the Creative Commons Attribution (CC BY) license (http://creativecommons.org/licenses/by/4.0/). 